\title{
ANTI-COLONIAL MESSAGES IN AHMAD SANUSI'S TAFSIR MALJA' AL THALIBIN AND TAMSIYAT AL MUSLIMIN
}

\author{
Lutfi \\ University of Canberra, Australia \\ E-mail: lutfi.lutfi@canberra.edu.au
}

\begin{abstract}
This research examines two tafsir works of Ahmad Sanusi Malja' al thalibin fi tafsiri kalami robbil alamin (in Sundanese) and Tamsiyat al muslimin fi tafsiri kalami Robbil Alamin (Indonesian Bahasa), exploring the messages of anti-colonialism related to justice. This research employs Hermeneutics for the analysis of Sanusi's messages. This approach provides understanding the social, political, cultural context of the production of the text. This study shows that tafsir has been an inspiration, medium, and tool to shape anti colonial awareness among Sundanese people particularly in Sukabumi region. The resistance is aimed at the Dutch colonial government as well as the religious bureaucrats well known as Pakauman Ulama. Among Sanusi's criticism that he delivers in his tafsir is about an injustice act done by the colonial government in particular Pakauman Ulama on his isolation as they give support to the exile policy. Historical context of Sanusi's isolation caused by the conflict between Sanusi and colonial government and the worry of the influence of Sanusi's ideas of anticolonial sentiment among people. In the literature of tafsir studies so far, it is limited discussion on tafsir material on criticism or as medium of resistance.
\end{abstract}

Keywords: tafsir; anti-colonial; ahmad sanusi; ulama; struggle

Abstrak. Penelitian ini mengkaji dua karya tafsir Ahmad Sanusi Malja' al thalibin fi tafsiri kalami robbil alamin (dalam bahasa Sunda) dan Tamsiyat al muslimin fi tafsiri kalami Robbil Alamin (Bahasa Indonesia), menggali pesanpesan antikolonialisme yang berkaitan dengan keadilan. Penelitian ini menggunakan Hermeneutika untuk menganalisis pesan-pesan Sanusi. Pendekatan ini memberikan pemahaman konteks sosial, politik, budaya dari produksi teks. Kajian ini menunjukkan bahwa tafsir telah menjadi inspirasi, media, dan alat untuk membentuk kesadaran anti kolonial di kalangan masyarakat Sunda khususnya di wilayah Sukabumi. Perlawanan tersebut ditujukan kepada pemerintah kolonial Belanda serta para birokrat agama yang dikenal dengan sebutan Pakauman Ulama. Di antara kritik Sanusi yang ia sampaikan dalam tafsirnya adalah tentang tindakan ketidakadilan yang dilakukan oleh pemerintah kolonial khususnya Pakauman Ulama atas pengucilannya karena mereka mendukung kebijakan pengasingan. Konteks historis keterasingan Sanusi yang disebabkan oleh konflik antara Sanusi dan pemerintah kolonial dan kekhawatiran pengaruh gagasan Sanusi tentang sentimen antikolonial di kalangan masyarakat. Dalam literatur kajian tafsir selama ini, pembahasan materi tafsir sebatas kritik atau sebagai media perlawanan.

Kata Kunci: tafsir; anti-kolonial; ahmad sanusi; ulama; berjuang

Permalink/DOI: https://doi.org/10.15408/mimbar.v38i1.24185 


\section{Introduction}

In literature about the history of the ulama struggle in Indonesia, the theme of resistance against the oppression and the justice enforcement have been issued based upon the religion order, i.e. the command of Jihad in the way of Allah. This then has become the main theme in the resistance movement of the ulama against the colonial government and a motivation for independence movements as seen from Sheikh Daud al-Fathani and Sheikh Abdul Samad al-Palimbangi fighting against the occupation of Siam (Azyumardi, 2013; Laffan, 2011); Sheikh Nawawi al-Bantani triggering the spirit of the people's struggle for the nation independence from Mecca; Sheikh Yusuf Makassar fighting against the Dutch in Banten (Vlekke, 2008). It is also found in Boland (1983) stating that spirit of jihad is the basic motivation to free from the colonization for Indonesian independence. For example, Nahdhatul ulama on October 22nd, 1945, declared the resolusi djihad (jihad resolution) as an authoritative fatwa to resist against the Dutch.

The history of Indonesian national liberation cannot be separated from the role of the ulama (Islamic scholars) in resisting colonial power (Sulasman, 2012). During the 1920s and 1930s, Indonesian ulama began to articulate a rising anti-colonialism and national consciousness as "Indonesians" (Bakti, 1993) and Indonesian political activism increased through these years as culminated in the declaration of Indonesian independence on 17 August 1945 (Ricklefs, 1993). The anti-colonialism movement was the striking phenomenon that emerged during the colonial period in Indonesia and in this period Ulama struggled through many forms of activism and mobilized people through the organisation (Shiraishi, 1990), religious educational institutions (Laffan, 2003), and expressing ideas through newspapers, magazine, and books (Boland, 1983). Tafsir is one of the forms of religious publication which has become the medium to spread the idea of anti-colonialism during revolutionary period.

The word of tafsir is derived from the Arabic word fassara, which means to lift the curtain, to make clear, or to show the objective. The word tafsir is the Arabic word for exegesis commonly is the Qur'an. The experts on tafsir generally define the word as a body of knowledge aimed to understand the meaning of the Qur'an, its injunctions, laws and wisdom (Al-Zarkasyi, 1957). Tafsir, is an important key to the Muslim understanding of the words of God and it is a holy activity in order to show the right path and salvation to the people. Understanding the Quran as part of social life has crucial role in providing solution on issues and responding the condition occurred in the society.

Tafsir, is an important key to the Muslim understanding of the words of God and it is a holy activity in order to show the right path and salvation to the people. Understanding the Quran as part of social life has crucial role in providing solution on issues and responding the condition occurred in the society. In Sanusi's context, where he faced many challenges on injustice and oppression, then he tries to link the messages in the Quran regarding the command of jihad and justice enforcement, strengthen the knowledge and building solidarity among ummah (community) to resist against colonial power. This shows that social context could be one of material in Tafsir (Zulaiha 2017). This style of tafsir contain materials in which exegetes deliver their criticisms and messages of resistance of the sociopolitical conditions, including tafsir malja al Thalibin. Campanini (2011) points out that this kind of tafsir in particular emerged in nineteenth and twentieth century as a hermeneutical reading of the Qur'an as a mufassir (exegete) transfers the meaning of Qur'anic text into his own horizon including values and meanings. This study explores further the Quranic exegeses as a medium of resistence against colonialsm in the tafsir malja al thalibin and Tamsiyat al Muslimin of Sanusi. More specifically, this 
paper deals with Sanusis's criticism of the colonial government in the theme of justice. The colonial government in this paper referred to the Dutch colonial and religious bureaucrats referred to Pakauman Ulama.

This paper deals with Sanusi's anti colonial criticism of the Dutch colonial government including religious bureaucrats in the tafsir malja althalibin and tafsir tamsiyat almuslimin. He wrote them while he was in exile. Tafsir Malja' al Thalibin contains the anti-colonial criticism written in the Sundanese script, which circulated 1931-1932 (Rohmana, 2015). The second is tafsir Tamsiyat al Muslimin issued in October 1934 contains messages about the importance of justice, self-esteem, freedom, brotherhood, and equality among the Ummah (Community). According to Matin (2009) this book was famous in Indonesia i.e Java, Madura, Sumatra, Borneo, Celebes, Menado, Ambon, Flores, Bangka, Sumbawa, as well as Johor and Singapore. The anti-colonial messages contained in his tafsir showed his deep understanding of the social and political issues he dealt with. Therefore, it can be said that what he did was an attempt to link the teachings of the Holy Qur'an with that the political events and situations occurring during the colonial era and this situation influence the way how Sanusi interprets the Quran as Syamsuddin (2009) says that the horizon of an exegete will always be carried in dealing with texts. Similarly, Saeed (2005) points out that social, political and intellectual contexts influence the way how the exegete approaches the Qur'an.

This research emerged after realizing that there is no available literature discussing about Sanusi's thoughts about anti-colonialism messages, particularly related to justice, as one of the most important aspects in his interpretation. There are several writings with the theme about Sanusi and his tafsir; the closest one of which is research by Rohmana (2015) entitled Al-Qur'an wa al-Isti'mar: Radd al-Shaykh al-Hajj Ahmad Sanusi (1888-1950)' alá al-Isti'mar min Khilal Tafsir Mal'ja' al-Talibin. However Rahmana only focus on Sanusi's criticism in tafsir maja al thalibin, while this paper focuses on two Sanusi's tafsir both tafsir malja althalibin and tafsir tamsiyat almuslimin and outlines Sanusi's anti colonial resistance messages related to justice issue.

\section{Map of Sanusi's Intellectual}

Sanusi was an 'Aalim (an Islamic scholar) of pesantren who contributed to Indonesian independence through many forms of struggle such as, an organisation called al Ittihad al Islamiyyah, Pesantren itself namely Pesantren Gunung Puyuh and his ideas through his numerous writings both in Sundanese and Indonesian Bahasa. Bruinessen (1990) noted Ahmad Sanusi as one of three original Sundanese writers, who was also involved in debates on religious affairs with reformist as well as with his fellow Pakauman ulama (Darmawan 2009).

He was born in the Cantayan Village, Onderdistrik (Subdistrict) Cikembar, Cibadak District, Afdeeling (section) Sukabumi on 12 Muharam 1306 Hijri (Falah, 2009) or on 18 September 1888. Sanusi was the third of eight children of Abdurrahim and Epok, his first wife. In his childhood, he was raised in a religious environment. Sanusi received religious education from his parents who had founded a pesantren (Islamic boarding schools) named Pesantren Cantayan.

When Sanusi was 16 1/2 years, he not only obtained religious education from his parents, but also several ajeungan (the leader of pesantren in West Java area and is a call for an expert in Islamic teaching) around Sukabumi namely Cisaat, Cijambe, Sukaraja, Gentur, and Majalengka. Besides, to 
deepen Islamic knowledge, Sanusi also studied in several pesantren outside Sukabumi, namely pesantren Gudang (Tasikmalaya), Garut, and Cianjur (Sipahoetar, 1946). Sanusi spent his education in pesantren outside Sukabumi for $4 \frac{1}{2}$ years and in 1909 returned to Sukabumi and attended the Pesantren Babakan Slaawi. While he was studying at the pesantren, he met with Siti Juwariyah, the daughter of Affandi (the leader of Pesantren Babakan Slaawi) from Kebon Pedes, Baros District, Sukabumi. In 1910, Sanusi married Siti Juwariyah and a few months later, Sanusi and his wife went to Mecca to perform the pilgrimage (Iskandar, 1993; Sipahoetar, 1946) and to deepen his Islamic knowledge. He then learned from several local scholars and scholars who came from abroad, these scholars were from the Syafi'i school of thought. Some of the teachers were Muhammad Junaedi, Mukhtar, Abdullah Jamawi, and a mufti from the Syafi'i school called Shaykh Saleh Bafadil (Iskandar, 1993).

When Sanusi stayed in Mecca, he read the ideas of Muslim modern reformist such as Muhammad Abduh and Rasyid Ridha. According to Matin (2009) Sanusi's ideas were influenced by them. Rohmana (2015) revealed that, during his study in Mecca, his spirit of nationalism came up as proven from his defence to Sarekat Islam that was slandered for not fighting for the Islam interests. To respond, Sanusi wrote a defence book entitled Nahratuddargham. Although he officially resigned from Sarekat Islam in 1916, in reality, Sanusi's membership had been suspended (Falah, 2009). He, once returning from Mecca, began to get involved in conflict with traditionalist and reformist, particularly in relation to any religious practices. Sanusi also began to criticize the colonial government for any policies that were anti-social, as occurred in zakat (Alms) distribution. The government in running the power saw Sanusi as a barrier; hence, the government sought the way to exile Sanusi from his place and people. Eventually he was accused of many cases such as his involvement in Afdeeling B in 1919; his resistance of Menes Banten Indonesia in 1926; and the destruction of the telephone network in Sukabumi in 1927. All of this resulted in continuous monitoring by the colonists. He was arrested in Cianjur and Sukabumi in 1927. Since November 1928, Sanusi was exiled to Tanah Tinggi, Senen, Batavia Centrum without being charged of any offense, and finally, he become city detainee in Sukabumi from 1934 to 1942 (Falah, 2009). The exile was due to the worries of the government about Sanusi's anti-colonial ideas that were considered potentially causing trouble in society. The detention has shaped his character and personality and strengthened his anticolonial ideas expressed through his writing which were later published into books distributed to the public for wider circulation.

The exile had a positive impact on Sanusi. As he produced numerous works on issues brought to him and clarified matters regarding religious practices and publishing various books. While in exile Sanusi continuously taught his student through different media. Religious material was delivered to students and his jama'ah (congregation) was through books, for example, Tafsir (the Qur'anic interpretation), he routinely wrote it down in several books (bulletins) which he regularly published while in Batavia Centrum, Despite being away from his socio-cultural environment, he did not leave the education process. The kyai who replaced Sanusi at the pesantren used these materials in his teaching. Sanusi survived during his exile in Batavia Centrum by writing and selling his books to the public (Sipahoetar, 1946). His productivity is apparent from the long list of his works reported by himself to the Japanese Military Government in 1942 (Falah, 2009).

Besides writing various religious books, Sanusi was actively engaged in publishing. He managed several magazines that discuss religious matters. In March 1931, Sanusi published a monthly magazine called Al-Hidajatoel Islamijjah. In addition to publishing Al Hidajatoel Islamijjah, Sanusi also 
published a magazine that contained the tafsir of the Qur'an was in Sundanese. This magazine was used as a teaching material by religious scholars and teachers, teaching the Qur'anic tafsir to their students.

Sanusi was a prolific writer and extensively wrote about theology, sufism, Islamic jurisprudence and tafsir (Nurtawab, 2009). Sanusi has left hundreds of Sundanese writings after his death (Basri, 2000) and according to the Puslitbang (development and research centre) Lektur of the Department of National Religious Affairs in Jakarta, Sanusi left four hundred and eighty (480) pieces of works. However, many of these works are out of circulation and difficult to locate as Matin (2009) stated that only one hundred and twenty-two (122) pieces of Sanusi's writings can be found today mainly because the publication of the works was prohibited by the Dutch considering his writings as a threat to the colonial authority. Those who owned Sanusi's works hid them for fear of persecution by the Dutch administrators and according to Shaleh (2009) some are not available in Indonesia as they are in Leiden and some of them are not available for sale or purchase.

\section{Sanusi's Anti-Colonial Messages on justice}

Sanusi's main concern of his struggle is to enforce justice and resist against the oppression and injustice. Sanusi argues that justice is one of the crucial pillars for establishing the prosperous country as he illustrated an ideal nation by explaining Surah al-Baqarah verse 31 stating that a prosperous country must be supported by five points: the knowledge of Ulama, fair kings or leaders, the worship of pious people, honesty and sincerity. He added that such ideal condition will not be realized due to the impacts of evil's trickery. Satan always teaches the human about things contradicting to the five aforementioned points. Sanusi stated that Satan always attempts to get into the hearts of the Ulama to make them always carry out provocation, hatred, and enmity with one another to create separation. Furthermore, Satan teaches tyranny to create an unfair life; such cruel acts of the leaders in turn will lead to distress and chaos in society. Satan also tries to get into the hearth of people doing the worship to create a feeling of desire to be praised or being show-off; this then makes the worship meaningless without any social effects. Satan furthermore tries to obstruct humans from any honest acts, making human not to tell the truth with a purpose to create chaos. Finally, Satan teaches insincerity, falsehood and evilness to human. In turn, such satanic teachings will lead the world to be insecure and unprosperous (Sanusi, 1935). Based on this explanation, it seems that Sanusi would like to remind that Indonesia people has been ruled by "Satan" as seen from the facts in which there have been many conflicts and hatred among religious leaders or Ulama, many rulers have misconducted the people, and there have been many dishonesties and crimes.

Sanusi provided a description how injustice occurred in the pre-Islamic period that is inequality in the legal process. When Arab leaders killed ordinary people, there was legal enforcement but when ordinary people killed their dignitaries, then they were punished with Qisas (retaliation). But, after the arrival of Islam, the punishment process was changed to be more just where all people with high or low positions would get Qisas (Sanusi, 1934). This shows that Sanusi's view on justice hold on the equality before the law despite of different religion. With the equality before the law, Sanusi explained that everyone will accept for what he or she has done. He quoted Surah 2 verse 134 where every human being has his or her own responsibility, and this responsibility issue is linked later by quoting the hadith of the prophet stating: 
There is no difference between white people and black one, there is no difference between Arabs and non-Arabs, but with knowledge and good deeds. So, it is clear according to the aforementioned verses and hadiths that all humans are equal. What distinguishes is on their knowledge and practice or good characters. Thus, Islam calls for humans to mutually respect one another and not insult one another (Sanusi, 1935; 382).

This commentary confirms that his ideas on justice basically drawn from the Qur'an and prophetic tradition.

\section{Contextualization of Tafsir}

In tafsir malja al Thalibin and Tamsiyat al Muslimin, Sanusi always links his criticism against the dutch colonial and religious bureaucrats. This creates an impression that the main reason for this resistance was because the injustice act done to him in particular and the colonial act to Indonesian people. Sanusi's criticism on justice or what he calls "adip" mostly referred to his experience of injustice act done by the colonial government such as his expulsion.

The expulsion in Sanusi's context is the form of injustice as he explained when interpret Surah al Mumtahanah verses 8 and 9, which says: "Allah does not forbid you from those who do not fight you because of religion and do not expel you from your homes from being righteous toward them and acting justly toward them. Indeed, Allah loves those who act justly. "Allah only forbids you from those who fight you because of religion and expel you from your homes and aid in your expulsion (forbids) that you make allies of them. And whoever makes allies of them, then it is those who are the wrongdoers.

Regarding these two verses Sanusi interprets:

This verse instructs the Islamic ummah to be fair to all people from different religions and beliefs as long as they do not fight or expel Muslims from their homes. Islam is a peaceful religion, free from hatred and revenge against non-Muslims living in the Muslim countries and they will not be disturbed in the matter of religious rights and practices. From the beginning of the century of Islam history to the fourteenth century, there were no Muslims who destroyed or forced other communities to embrace Islam (Sanusi, 1937)

This interpretation emphasizes the justice enforcement to all humans and not being hostile to other because of religion and not expelling other. However, In this context, Sanusi was being expelled from his society by the Dutch as Sanusi was regarded as the troublemaker in the society, criticizing government's policy such as in the issue of distribution of Zakat (alms) and regarded as a threat to the authority as he had a huge influence in the society especially in West Priangan Sukabumi. Sanusi's resistance against the colonial government on his isolation was shown when he interprets surah al An'am verse 52 and 53 .

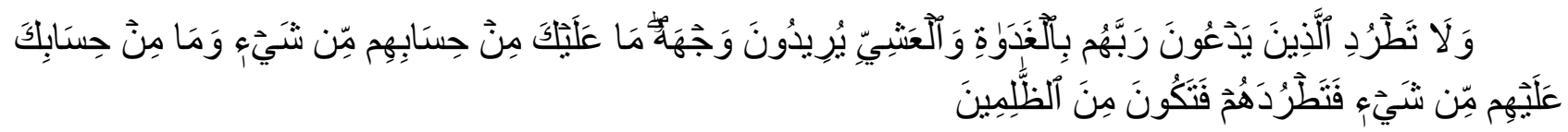

And do not send away those who call upon their Lord morning and afternoon, seeking His countenance. Not upon you is anything of their account and not upon them is anything of your account. So were you to send them away, you would [then] be of the wrongdoers". 
This verse was revealed as the Allah command to treat the rich and the poor equally. In the tafsir of Ibn Kasir (classical exegete), it is narrated about the reason of revealing this verse, as narrated by Ibn Jarir through the Ash'as route, from Kardus, from Ibn Mas'ud saying that a group of Quraysh leaders passed in front of the Prophet who at that time was accompanied by Suhaib, Bilal, Ammar, Khabbab, and others from the weak Muslims. Then the Quraysh leaders stated, "O Muhammad, are you willing to have these people as your people? Are they the people bestowed by Allah as among us? Is it appropriate for us to follow these people? Just get rid of them! Perhaps if you drive them away, we will follow you." Then, the words of Allah were revealed.

From the historical background of the revelation of this verse illustrates the request of Quraish leaders who listen to the prophet's da'wah (preaching) upon the prophet to expel other companions as they are from the poor people. Sanusi interprets this verse in Malja 'althalibin verse 52 and 53

Because you drive people away from their homes or just want to humiliate or hate others even though all those who professing Mu'min (believers) and Muslim must be glorified. So, if there are Muslims who like to drive away another Muslim brother, they are devils. Moreover, they claim to be an Islamic teacher, they are not Islamic teacher, but the devil teacher and they are Dajjal (Sanoesi, 1932; 160).

........Don't be arrogant or proud by looking down on the poor and the weak and other believers because Allah knows that those who are grateful to him will surely be given guidance in the world and because of their faith and obedient to worship then in the hereafter will get pleasure. However, no matter how rich and wealthy you are beware that the Hellfire is abode of the arrogant and unjust people (Sanusi, 1932; 161).

At the beginning of the sentence, as stated by Sanusi, there are 3 keywords, i.e. expelling, insulting, and hating. These three words, Sanusi said, should not be done by a believer to other fellow believers. Fellow believers should respect and glorify one another.

In the following sentence, illustrates Sanusi's justification by saying that those who have expelled are like the devil even though they are the respected persons in religion, i.e. ulama. Sanusi said that they are actually teachers of the devils, and a Muslims given with power and glory do not deserve to be arrogant to the poor. Sanusi emphasizes that those ulama who support the government aims to get the glory of worldly life through oppressing their own people.

Sanusi's interpretation above shows his criticism and resistance against the religious bureaucrats who treat Sanusi in injustice acts by isolating him from his community. Though it was not explicitly stated who expelled himself in this sentence. However, in this context, it can be concluded that the expulsion was done by the Dutch colonial government with the support of Ulama of Pakauman. The resistance demonstrates in this message using the harsh words (setan) to those bureaucrats symbolizing the evil.

Interesting to be explained, the term Satan stated by Sanusi in his interpretation as a call for the Ulama expelling him. If tracing, the term 'ulama' refers to people with a deep knowledge about Islam and has a higher position in Islam that is as the heirs of the prophets. However, in the context of Sanusi, Ulama was then defined as the devil - something bad. The word "setan" in the interpretation is a metaphor to describe the arrogance and tyranny of people who are in power in the name of religion. 
For him, anyone who looks down upon the Muslims and considers himself superior to them is like setan or Iblis.

In another example Sanusi calls those ulama who collaborate with the colonial government to gain such power and wealthy life as hypocrites. In this regard, Sanusi criticized and questioned some Muslim communities living under Dutch rule especially ulama supporting the Dutch authority, in interpreting Surah al Nisa from verse 138 to 139 which says:

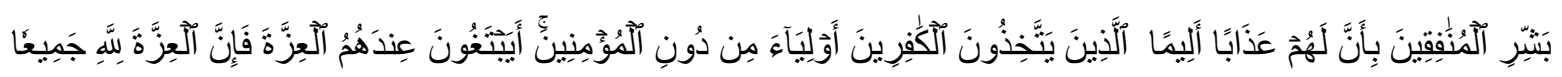

"Give tidings to the hypocrites that there is for them a painful punishment", Those who take disbelievers as allies instead of the believers. Do they seek with them honor (through power)? But indeed, honor belongs to Allah entirely.

Sanusi interprets that "God will give glory and nobility to the people whoever He wants, and hypocrisy or insulting his nation and disrespect their people are not the way to achieve the glory in the world but become a path to hell” (Sanusi, 1931). According to Sanusi, a hypocrite is a person that physically looks like a believer but inwardly is a disbeliever. Sanusi viewed that the hypocrites were twofaced people similar with chameleons and traitors to the nation for being spies for the invaders. Sanusi emphasized that the independence and glory of the Indonesian nation would never be obtained as long as there were hypocrites and harass their fellow countrymen. It can be concluded that the word munafik as stated by Sanusi was addressed to the bureaucrat ulama seeking power and world enjoyment by betraying their people and becoming the accomplices of the rulers to control or become the spies for the rulers in society (Sanusi, 1931).

In next verse 53 in surah al an'am Sanusi confirms that those ulama who collaborate with the colonial government as zalim (the wrong doers). According to Sanusi they are oppressor and not deserved to be a leader, and he banned people from making a friend with those who ignore justice and drive people away from their homeland. According to Sanusi they are not such a good leader and have no capabilities in protecting their people so that people should not follow their commands. Sanusi criticized them by his comment on Surah 2 verse 124 that leaders do not deserve to do wrong; they should have a task to prevent any injustice.

The zalim (wrongdoers) as those who have no compassion for fellow creatures are the people who do not deserve to be the leaders of creatures, or even to manage humans. The caretaker in essence is to protect every creature from injustice. Say, an Arabic proverb says whoever orders a tiger to herd the goats, it means to let the tiger eat the goat (Sanusi, 1934; 348).

It means that the two messages of Sanusi above calls for not to be led by a zalim because he or she will not be capable of protecting people; he or she even torment the people. Hence, Sanusi emphasized that if the leaders are good to the people, the people also will be good, as stated in Surah 2 Verse 129. Sanusi says that if all the children and grandchildren of the prophets are good, all humans will be good. Therefore, it has been seen from the past if the Ulama and dignitaries and leaders of a group or a people behave properly and obey their religion, their people will have good behavior and obey their religion too (Sanusi, 1934; 362).

Sanusi also warns people not to make a friend with them and even with their relatives if they oppress others. Sanusi says "Muslim community not to take the wrongdoers as their friends even they 
are their relatives". This statement is mentioned when Sanusi interprets Surah At-Taubah verse 23, which states: "O, you who have believed, do not take your fathers or your brothers as allies if they have preferred disbelief over belief. And whoever does so among you - then it is those who are the wrongdoers. And the next verse says:

Say, [O Muhammad], "If your fathers, your sons, your brothers, your wives, your relatives, wealth which you have obtained, commerce wherein you fear decline, and dwellings with which you are pleased are more beloved to you than Allah and His Messenger and jihad in His cause, then wait until Allah executes His command. And Allah does not guide the defiantly disobedient people."

Sanusi wanted to show that the obligation of jihad against tyranny should become a priority rather than family or material life. He interprets above verse saying:

This verse instructs the prophet, Muhammad, to those who love their kufr more and leave their faith, love their father, children, siblings, wife, friends, the commerce in which one fears a decline, and the dwelling in which one delights are more loved by all of them rather than migrate to religion Allah and his apostles, and more loved than jihad in upholding the religion of God, then they will get the torment of God in this world and the hereafter. Allah's punishment in the world is that they are made insulted, weak, poor, miserable. God will not give happiness and glory in this world and in the hereafter to all wicked people and who do not obey God's commands (Sanusi, 1931; 120).

From his explanation above, Sanusi regards those who support the colonial government even they are Muslim as an oppressor and no need to obey them as they don't obey God's will, so they will be punished both in the world and the hereafter. Giving satire and analogies, a country and people will be good and developed dependent upon who is leading. Thus, Sanusi argued that the leader plays an important role. If the religious leader oppresses their people, then chaos, destruction and humiliation among people will occur. Sanusi describing the relationship between ulama and the colonial rulers who oppressed their people by telling a story from a time before the coming of Islam.

Before the arrival of Islam, humans were divided into three groups: worship experts, state rulers and public. The religious scholars occupied the highest position, while the rulers were in second place. These two factions worked together to oppress their people for the benefit of the world. The religious leaders oppressed society in the name of religion and treated people like goats and the rulers oppressed them in the name of their power. After the arrival of Islam, Islam stipulated that all humans have the same rights without any superiority between one another but knowledge, roles and good deeds. (Sanusi, 1934, 381-382).

Sanusi satirically reminded the rulers by saying that human power is like a shadow as illustrated in the explanation of Surah Al-fatihah verse 4 "maliki yaumiddin" talking about that Allah owns the power. Sanusi stated that true power belongs only to Allah and the power owned by other than Allah is like a shadow. Inevitably, if the one who holds the power dies, the power will also disappear.

In this world, there are many who claim to be kings and rulers other than Allah, their power is like a shadow, and after their death, there is no more power and kingdom (Sanusi, 1931;10). 
What Sanusi stated is a satire addressed to the unjust rulers, particularly to the ulama giving a support to the clearly oppressive government. According to Sanusi, the source of zulm is related to the orientation of power and the world life. Sanusi interprets surah Ali Imran verse 108 that an injustice act done by people because of their interest in the worldly life and the authority.

...the existence of injustice because of the desire to increase wealth or glory or want to increase power or want to perfect deficiencies.....(Sanusi, 1931:316).

According to Sanusi the wealth and power could be the source of injustice. When these two things have become the goal of life, all means will be carried out even if they take the wrong path. In other words, the religious elite who support the Dutch colonial policies or interests according to Sanusi they were tyranny because they gave support to the tyrannical Dutch solely because of their interest to the glory of life and power.

\section{The obligation to fight against evil and injustice}

By explaining that fighting against zulm is the obligation of Muslim, Sanusi always invited the people of Priangan to fight against the colonialism. If there are Muslims claiming to be Muslims but having no concern about the struggle, they are not the Moslem indeed. According to Sanusi, a Muslim who fights and then dies in the struggle will have a status as Syahid (martyr). As stated in Surah 7 verse 29, Surah 3 verse 114 and Surah 3 verse 21.

Sanusi's call for fight against injustice also is demonstrated from his interpretation of Surah 3 verse $110, ”$

.....To enjoin people to do the good deeds and forbid people from doing bad is compulsory to every Muslim, unless he is not called as a Muslim and this verse teaches us the obligation of those who are oppressed to enjoin them what is right and forbid what is wrong and resist against their oppression. Thus, if someone is killed, he is martyred in the path of God (Sanusi, 1937).

He also quotes the hadith from Abu Sa'id Al-Khudri reported: Messenger of Allah said, "Whoever amongst you sees an evil, he must change it with his hand; if he is unable to do so, then with his tongue; and if he is unable to do so, then with his heart; and that is the weakest form of Faith". Based on the prophet's saying, Sanusi interprets that anyone who sees evil should prevent it with his hands if he has no power then he must eliminate it with his mouth. If he does not have the power to get rid of evil with his mouth, then he must deny and hate with his heart, and this is the weakest part of faith. So that the purpose of this verse is obligatory upon Muslims in each place to teach and call for good. In addition, Sanusi reaffirmed the importance of fighting the zulm / wrongdoings; and people who remain silent and not fighting against it actually allow the wrongdoing occurs and as a consequence they will get humiliation.

The call of Sanusi to uphold justice and fight against colonialism was basically to see the Indonesian people free from any forms of oppression and free to manage themselves, free to determine their own destiny without being dictated to by other nations as in line with the aspiration of Indonesia people stated in the Preamble of the 1945 Constitution stating "this independence is the right of all nations and therefore any colonialism in the world must be abolished for not being in line with humanity and justice".

In Surah 2 verse 45 Sanusi strengthened the determination to keep on fighting and never to give up in upholding the truth and to always ask Allah for helping, as he stated when interpreting the verse. 
If you meet a group of polytheists who will destroy you all on the battlefield, then strengthen your heart, body, energy and rules to keep you can keep going and never going back, and never expelled. And remember to always ask Allah for helping and being kind to Allah and remind and carry out all commands of Allah (Sanusi, 1931; 55).

In Surah 2 Verse 155, Sanusi described the test of Allah to mankind consisting of fear, hunger and lack of wealth. In the word khouf (fear), he added an information by saying "because of being afraid of the unjust enemy"(Sanusi, 1931: 122). This statement shows the condition of fear in the community because of the oppression by the Dutch colonial. Then, it was continued by saying that if being affirmed in practicing the religion even though being fear in facing the zulm, it is firm when facing the death. Here, Sanusi wanted to strengthen his followers and those fighting to expel the Dutch to fight against wrongdoing rulers. He stated "manka ulah siyeun maneh kabeh dina ngajalankeun agama ku jalma-jalma kafir" (So you all, do not be afraid of practicing religion against unbelievers) (Sanusi, 1931: 119). Because being fear is only for Allah alone as stated in his interpretation in Surah 2 verse 194.

Be fear of Allah in this matter, be aware! of helping unjust people who like to abuse others, be aware! of not being dared to fight against the zalim / wrongdoer (Sanusi, 1931: 152).

In the above interpretation, Sanusi conveyed not to be afraid of the tyranny of the authorities. This is a clear warning and invitation Sanusi gave to the people to fight the Dutch at best.

In Surah 3 verse 139, Sanusi assured that Muslim must not be weak in upholding and advancing Islam, It needs a patience to undergo the test of tyranny because there will be the best punishment both in the world and in the hereafter as long as every Moslem keeps the faith, and does not behave like hypocrites or wicked. Furthermore, Sanusi illustrated how the prophet Muhammad's companions controlled the world at that time in view of their faith and patience and far from being hypocritical and wicked (Sanusi, 1931; 337). In other words, Sanusi stated that hypocrites and wicked people are those with the weak in faith. They cannot stand the test just because of a lure from the world and their power is determined and trapped in a wrongdoing circle.

Sanusi gave a confidence and optimism to the community that the truth will win as seen when he interpreted verse 6 and at the same time, he warns the wrongdoing rulers that will be destroyed.

It is clear that every corrupt age will be replaced by another era. Thus, this verse warns all humans to take the example of the old people who did not want to worship Allah and did not want to obey their prophet. God has removed the mighty, strong and rich people from this earth. So if people today like this, they will be destroyed by Allah (Sanusi, 1931; 130)

The point that can be taken from the interpretation is that we must be aware that if corrupt and injustice exist among people in an era. Then, it must be remembered that there will be a time to collapse and perish. It certainly occurs as they do not obey Allah and His prophet. Sanusi's calls for a fight against the oppression to warn people who are a passive attitude towards the colonial conditions. A person silent about zulm/wrongdoings according to Sanusi means approving the zulm (wrongdoing) and he or she is included as the wrongdoer and will be equally humiliated even though that person is an expert in worship. It is because he or she basically has violated any Allah's orders. Sanusi explained that there are commands from Allah relating to the affairs between himself and Allah. There are also the 
commands of Allah related to social. It is interesting with what Sanusi explained in this regard, say, he stated:

So, if there are people who are diligent in worshiping Allah but do not like to command goodness and prevent evil, then that person is unable to take care of himself because he has left Allah's commandments. As the Prophet said, "By Allah, it is obligatory for you to command goodness and prevent badness, otherwise there will be someone who will rule you with evil and injustice so that you are tormented, and your prayers will not be granted. As in the prophet's words, if there are people that do not prevent evil and it is not denied, then Allah will torture and all of his or her wishes will not be granted... (Sanusi, 1931; 106).

Sanusi emphasized that people when seeing the immorality do not do anything, will be treated equally, meaning that they will also be cursed by Allah. This might illustrate how many Muslims are silent and do not even fight against the evil and injustice occurred. This is explained by Sanusi in interpreting Surah 8 verse 25 stating that Allah will give torment to the zalim or wrongdoers and those close to, being friended with, living in one place and working with the wrongdoers. As told by Imam Al Baghawi, Allah will not torture a people with one sin. A person who knows and sees any wrongdoings but then being silent and not prohibiting; in fact, he or she is able to stop it, then Allah will torture all who do immorality as well as those not doing immorality ... (Sanusi, 1931; 29-30). In other words, if there are people who are not ready to fight against the Dutch, then he or she is included as those doing immorality as done by the colonialists or those considered to support the colonialists. Then he or she become the cursed people.

\section{Historical Context}

To explain the messages of upholding justice and fighting against colonialism above, it is important to see the socio-political context where Sanusi lived, and it will be described below.

In the 1920s, there were several religious problems that resulted in debate between Sanusi and the Pakauman ulama such as zakat (alms). The procedure for withdrawing and collecting zakat was opposed by Sanusi because as against the Qur'an and Sunnah. Even in the rules issued by the government, zakat was not to be regulated by them because the government would not interfere in Islamic matters. But the government was not consistent and regulated zakat despite was being an Islamic matter. Pakauman ulama as representative of the government withdrawn the zakat fitrah and zakat maal from Muslims which were carried out by amil (Zakat administrator). $70 \%$ of zakat fitrah and maal were forwarded to hoofdpenghulu or head chiefs domiciled in the regency. The remaining $30 \%$ belongs to the amil as his salary, so that zakat collected did not reach the mustahiq (the people who deserve to receive zakat).

Sanusi argued that the issue of zakat fitrah and zakat maal was a matter for Muslims and not for the government, hence Amil who was in charge of collecting zakat fitrah and zakat maal should be appointed by the community rather than by the government. The collected zakat was then distributed to the people who were mustahiq accordance with the teachings of the Qur'an and Sunnah (Sanusi, n.d).

Sanusi's opinion turned out to be very influential among the people of Sukabumi because they realized that the government abused the distribution of zakat. The people of Sukabumi accepted the 
fatwa issued by Sanusi rather than by Pakauman ulama. This can be seen from the fact that at least until the beginning of 1928, people who gave up zakat fitrah and zakat maal to amil appointed by the government, decreased (Iskandar, 1993). In contrast, zakat fitrah and zakat maal received by amil appointed by the public are increasingly being collected (Iskandar, 1993).

Sanusi's opinion on the issue of zakat was strongly opposed by Pakauman ulama who were driven by K. H. R. Ahmad Juwaeni, Hoofd penghulu of Sukabumi. This is understandable as their income from zakat would have decreased. They viewed Sanusi's opinion as a fatwa as threat to the authority of the Pakauman ulama in the society.

Sanusi's criticism related to mismanagement in the process of zakat implementation carried out by the government was actually to emphasize that the function of zakat should have contributed to improve the social welfare as stated in the Holy Qur'an. In fact, zakat oppositely only benefited the government that was supposed to be a facilitator and the poor people came to be more depressed. This was the core of Sanusi's criticism in the process of implementing zakat by the government. Another point of Sanusi's criticism regarding zakat case is his resistance toward the abuse of power done by the officials namely corruption of people's money on behalf of religion.

When there was no solution found in terms of the issue of zakat, Sanusi refused to hold any Selamatan (celebration) for Muslims who had passed away. At that time, even today, in religious practice among the people there is a tradition, called the death ceremony on the third day, seventh day, and so on. For him, the death ceremony in Islam law is Makruh (a disliked act). If the death ceremony is stated as a stipulation of Islamic, then it is seen as haram (forbidden) for there is no single verse in Holy Qur'an regulating such ceremony. In his view, the death ceremony is a mere karuhun (inheritance) that does not have any religious legal implications if not done. In fact, it should be abandoned as it is closely related to shirk or polytheism. Therefore, Sanusi viewed the death ceremony as dhiafah, or the alms of death (Sipahoetar, 1946).

Sanusi's thought about the death ceremony again received a strong reaction from the ulama of Pakauman. K. H. R. Uyek Abdullah was a figure of Pakauman Ulama who strongly opposed the fatwa of Sanusi. He was the brother of K. H. R. Ahmad Juwaeni, the Hoofd Penghulu Sukabumi as well as the head of the Pabuaran Islamic Boarding School. He was also a member of the Raad Igama (religious institution) Sukabumi and was the Imam (prayer leader) of Sukabumi Grand Mosque. In terms of the death ceremony, Kyai Uyek believed that the ceremony did not include the problem of dhiafah and it is not haram. The death ceremony is seen as a form of alms for Muslims; thus, it is permissible.

The two opinions expressed by two influential ulama then led the people in Sukabumi into confusion. On the basis of maintaining the peace, K. H. R. Ahmad Juwaeni brought the two kyai together in an open debate. In the debate held in 1922, both Sanusi and K. H. R. Uyek Abdullah agreed that a death ceremony may be held as long as it is intended to give alms without any the provisions of a certain day i.e. third day, seventh day, fourtieth day, and so on. In addition, the ceremony may be held as long as it is not included as a religious provision (Iskandar, 2001). After the debate, the police always monitored the daily activities of Sanusi in which his public recitations were increasingly closely monitored with the consideration to that it was potential to have a strong influence among the congregations. The government's concern was acceptable as the recitations not only discussed about religious issues but also discussed about social and political issues. 
Furthermore, Sanusi's fatwa on prohibiting people from giving prayer to the regent in the jum'ah prayer as known as the case of abdaka maulana makes the bureaucrats angry and regards this fatwa as an insult at them. Because of this issue the bureaucratic elite tried to convince the Dutch East Indies Government to arrest Sanusi. And finally, because of several cases accused to Sanusi which could not be proven, such as in August 1927, there was the destruction of two telephone wire networks connecting Sukabumi, Bandung and Bogor, the incident occurred was used as preliminary evidence by the Netherlands Indies Government to arrest and detain Sanusi. The reason given by the Dutch East Indies Government was that one of the damaged telephone networks was not too far from Sanusi's Pesantren (Iskandar, 1993).

For this reason, the Dutch East Indies Government isolated Sanusi in the prison at Cianjur. He stayed in the prison for nine months until May 1928 he was transferred to a prison in the City of Sukabumi (Sipahoetar, 1946). For eleven months, he was interrogated by the colonial government, but there was no evidence that he was involved in the incident. However, the colonial government did not immediately release Sanusi and even implicated him to the events of the Kyai Asnawi resistance in Menes, Banten, which occurred in 1926 (Mawardi, 2011).

The bureaucrats' witness testimonies who had previously been briefed to incriminate Sanusi were considered sufficient, all witnesses said that Sanusi had a relationship with K. H. Asnawi so that their testimonies were considered sufficient to serve as preliminary evidence for his detention. However, in the interrogation process, the colonial government could not prove the connection between Sanusi and Kyai Asnawi. On the other hand, witnesses who previously made statements regarding the relationship of Sanusi with Kyai Asnawi retracted their testimony. In other words, they were forced to make false testimonies that were intimidated by the local police and district officers. Nevertheless, the colonial government kept Sanusi in detention (Iskandar, 1993).

Although there was no evidence of Sanusi's involvement in the Kyai Asnawi resistance (1926) and the destruction of the telephone network (1927), Governor-General B. C. de Jonge issued a decision to exile Sanusi to Tanah Tinggi in Batavia Centrum, the order officially implemented in November 1928. The Dutch East Indies government said that the detention was to maintain public peace because Sanusi's thoughts have the potential to influence people to resist against the government. To prevent the development of this potential, the Dutch East Indies Government deemed it necessary to alienate Sanusi from his socio-cultural environment (Iskandar, 1993; Sipahoetar, 1946).

\section{Conclusion}

To understand the ideas of resistance from Sanusi, it is important to consider the context and conditions of colonialism occurred in Indonesia and more specifically for Sukabumi area where Sanusi was born and lived. Under a colonial condition, Sanusi viewed that struggle to uphold the truth was religiously obliged. He explained that it was the duty of everyone as a Muslim to fight against injustice and took an action as anyone who was not active in the struggle would not be called as a Muslim, and whoever fought and then died was a Syahid (martyr). In essence, Sanusi's ideas about resistance was to give awareness to Indonesian people to be not weak and relied on foreign parties and to foster selfconfidence that the Indonesian nation was a better than the colonial nation. 
The way Sanusi understood the Holy Qur'an was by using socio-political approach in making the tafsir for the messages in the Qur'an. He stated that justice in Islam was equality under law and guarantee for the rights of every human being - not based on race. All humans are equal, and the only difference is on what the humans do. In this case, Sanusi referred to the hadiths of the prophet asserting that there is no difference between white and black people but knowledge and deeds. Islam, as Sanusi viewed, invites people to respect one another and not humiliate one another. In his understanding, justice is one of the important keys to make a prosperous country.

In tafsir of malja althalibin, Sanusi interpreted justice as something related to his exile by the colonial government. This tafsir referred to the Quran in Surah Al Mumtahanah verses 8 and 9 where in this verse it is stated that expulsion is a part of injustice. The exile decision issued by the colonial government and religious bureaucrats for Sanusi was in view of the thoughts of Sanusi viewed to be able to influence the community to fight against the government. Using a provocative language, Sanusi mentioned the Ulama who supported the government in exile as "devil" as a symbol of arrogance and oppression of fellow nations. Also, in another example, Sanusi called them hypocrites and wrongdoers for supporting the interests of the Dutch infidels and for the sole purpose of power and materiality.

This paper showes that tafsir as a media for delivering anti-colonial messages in the Indonesian independence movement has a significance in forming a sense of nationalism and resistance to colonialism and other forms of injustice. This research makes four key conclusions, Firstly, Sanusi's ideas of anticolonialism is to free Indonesian people from any forms of oppression and be free to determine their own destiny without being dictated to by other nations. Secondly, Sanusi's struggle for Indonesian independence was inspired by Islamic teachings but do not support Indonesia to become an Islamic state rather argues for a nation state. Finally, Sanusi's criticisms toward the Dutch colonists and local bureaucracy, especially religious bureaucrats, uses religious language, namely Kafir (infidels) and Munafik (hypocrites) and Dzolim (tyrants) to illustrates his position of being oppressed by the authorities of his time.

\section{References}

al-Zarkasyi, 1957. Al-Burhan Fi 'Ulum al-Qur’an, al-Halabiy, Egypt.

Azyumardi Azra, 2013. “The Patani 'Ulama': Global and Regional Networks” dlm. Jory, P. (ed.). Ghost of The Past in Southern Thailand. NUS Press: Singapore.

Bakti, AMF 1993. Islam and Nation Formation in Indonesia, McGilI University Montreal.

Basri, Husen Hasan 2000. Warisan Intelektual Islam Indonesia: Telaah atas Tafsir Malja' at-Talibin dan Tamsyiyyat al-Muslimin Karya Kyai Haji Ahmad Sanusi 1988-1950. Skripsi. IAIN Syarif Hidayatullah Jakarta.

Boland, B. J. 1983. The struggle of islam in modern Indonesia, the Hague: Martinus Nijhoff, Leiden.

Bruinessen, M, V 1990. Kitab Kuning: books in arabic script used in the pesantren milieu, brill

Campanini, Massimo. 2011. The Quran: Modern Muslim Interpretation, Taylor and Francis

Darmawan, D. 2009. Ortodoksi Tafsir: Respons Ulama terhadap Tafsir Tamsjijjatoel-Moeslimien Karya K.H. Ahmad Sanusi, Sekolah Pascasarjana UIN Syarif Hidayatullah Jakarta, Jakarta. 
Falah, M. 2009. Riwayat Perjuangan K. H. Abdul Halim. Bandung. MSI Cabang Jawa Barat.

Iskandar, M. 1993. Kiyai Haji Ajengan Ahmad Sanusi.: PB PUI, Jakarta.

Iskandar, M. 2001. Para Pengemban Amanah: Pergulatan Pemikiran Kiai dan Ulama di Jawa Barat, 1900-1950. Mata Bangsa, Jakarta.

Laffan, M., 2011. The Making of Indonesian Islam: Orientalism and the Narration of a Sufi Past. Princeton University Press, New Jersey

Matin, UA 2009. 'K.H. Ahmad Sanusi (1888-1950): his religio-intellectual discourse, and his work Collection', Jurnal Lektur Keagamaan, vol. 7, No. 1, pp. 147-164.

Mawardi, Asep Mukhtar 2011.Haji Ahmad Sanusi dan Kiprahnya dalam Pergolakan Pemikiran Keislaman danPergerakan Kebangsaan di Sukabumi 1888-1950. Tesis. Semarang: Undip.

Nurtawwab, EN 2009, The Tradition of Writing Qur'anic Commentaries in Java and Sunda, Suhuf, Vol. 2, No. 2.

Ricklefs, M.C. 1993, A History of Modern Indonesia Since c.1300, MacMillan, London.

Rohmana, Jajang. A 2015. "Al-Qur'an wa al-Isti'mar: Radd ash-Syaikh al-Hajj Ahmad Sanusi (18881950) 'Ala al-Isti' mar min Khilal Tafsir Malja' aț-Ṭhalibin, Studia Islamika 22(1).

Saeed, Abdullah. 2005. Approaches to the Qur'an in Contemporary Indonesia, Qur'anic Studies Series. Oxford University Press in association with The Institute of Ismaili Studies.

Saleh, Munandi. 2016. KH. Ahmad Sanusi; Pemikiran dan Perjuangannya dalam Pergolakan Nasional, Jelajah Nusa, Tanggerang Selatan.

Sanusi, A 1931. Malja' at-Talibin fi Tafsir Kalam Rabb al-'Alamin. Batavia: Maṭba'ah Ahl as-Sunnah wa al-Jama'ah Harun bin 'Ali Ibrahim, jilid 1.

Sanusi, A. 1934. Tafsir Tamsjijjatoel Moeslimien fi Tafsir Kalam Rab al-'Alamin. Sukabumi: Masdoeki dan Al-Ittihad, nomor. 1-53.

Shiraishi, T. 1997, Zaman bergerak radikalisme rakyat di jawa 1912-1926, Pustaka Utama Grafiti, Jakarta.

Sipahoetar, A.M. 1946.Siapa? Lukisan tentang Pemimpin. Soekaboemi: Pertjetakan "Pemerintah". KITLV.

Sulasman, 2012. 'Kyai and Pesantren in the Islamic Historiography of Indonesia', International Journal for Historical Studies, Volume 4, No. 1, pp. 67-81

Syamsuddin, Sahiron. 2009. Hermeneutika dan Pengembangan Ulumul Qur'an, Pesantren Nawasea Press, Yogyakarta.

Vlekke, Bernad, H. M., 2008. Nusantara: Sejarah Indonesia, Kepustakaan Populer Gramedia, Jakarta.

Zulaiha, Evi. 2017. "Tafsir Kontemporer: Metodologi, Paradigma dan Standar Validitasnya." Wawasan: Jurnal Ilmiah Agama dan Sosial Budaya 2(1). 